\title{
Effect of additives on sintering response of titanium by powder injection moulding
}

\author{
A. Arockiasamy*1, R. M. German ${ }^{2}$, D. F. Heaney ${ }^{3}$, P. T. Wang ${ }^{1}$, M. F. \\ Horstemeyer $^{1}$, R. L. King ${ }^{1}$ and B. Adcock ${ }^{1}$
}

Powder injection moulding is a maturing technology that has proven most useful for the production of complex metallic and ceramic components of modest sizes. Considering the inevitable demand for cost effectiveness in automotive applications, components manufactured from low cost sponge titanium ( $\mathrm{Ti}$ ) powder currently reflect the most advantageous economics among the available Ti powders. This paper describes the net shape fabrication of Ti components and considers the role of iron and zirconium powder additions. Sintering cycle optimisation relied on differential scanning calorimetry to identify a cycle in the $1275-1300^{\circ} \mathrm{C}$ range for $1-2 \mathrm{~h}$. The sintered material was characterised using tensile and hardness testing and microscopic examinations. The influence of test conditions on densification, microstructure and mechanical properties was analysed.

Keywords: Titanium alloy, Powder injection moulding, Sintering, Mechanical properties

\section{Introduction}

Titanium (Ti) is a highly useful material in the production of components for various applications ranging from biomedical implants to automotive fuel injectors. At the same time, the high strength to weight ratio and high resistance to corrosion make $\mathrm{Ti}$ and its alloys ideal materials for many of these same applications. $^{1-3}$ However, a difficulty occurs in fabricating components at a low cost from an expensive material. Considering powder metallurgical production routes, simple die compaction offers limited shape complexity, therefore compaction is not useful in many small component designs. For other fabrication routes, cost is a primary concern; casting followed by machining is prone to defects and suffers from a low productivity. 4,5 On the other hand, the powder injection moulding (PIM) process offers a viable solution to these problems, especially the problem of cost of production. ${ }^{6-9}$

Powder injection moulding involves the injection moulding of a mixture of metal powder and polymer binder into a mould to produce a 'green' part, which is then debound and sintered into finished product.

Through much research since the late 1980s, it has been determined that the level of impurity elements, powder expenses and mouldability of the powder all have an effect on the success of Ti PIM. Impurities such

${ }^{1}$ Center for Advanced Vehicular System, Mississippi State University, 200 Research Boulevard, Starkville, MS 39759, USA

${ }^{2}$ College of Engineering, San Diego State University, 5500 Campanile Drive, San Diego, CA 92182-1326, USA

${ }^{3}$ Center for Innovative Sintered Products, Pennsylvania State University, University Park, PA 16802-6809, USA

*Correspondence author, email aanton@cavs.msstate.edu as oxygen can dramatically decrease the strength and density of Ti PIM products. ${ }^{10-12}$ Powder costs vary based on the grade of powder used for PIM, with high purity powders costing significantly more. Furthermore, more easily moulded powders whose particles are smaller and more spherical become more expensive which consequently increases the cost of production. Thus, in an economic analysis the processing difficulties from lower cost powders must be balanced against the ease of processing possible using a spherical Ti powder.

There are several cost factors evident in Ti PIM. These include powder handling ( $\mathrm{Ti}$ is pyrophoric), moulding issues from stiff mixtures and care during debinding and sintering to avoid interstitial contaminants, all factors beyond powder cost that influence production economics. The cost of injection equipment and associated power consumption is fairly modest, but equipment for debinding and sintering as well as the energy, atmosphere and long cycles for these processes vary greatly between PIM technologies. Thus, it is important to minimise the necessary thermal cycle duration while maximising quality of the Ti product. One way of achieving this goal considered in this study is to adjust alloying to enable Ti PIM shapes at low cost, with rapid cycles, and mechanical strength comparable to automotive applications. In this case iron $(\mathrm{Fe})$ and zirconium $(\mathrm{Zr})$ are used as alloying elements, ${ }^{13-15}$ as Fe

Table 1 Characteristics of powders used

\begin{tabular}{lcl}
\hline Powders & Particle size, $\mu \mathrm{m}$ & Pycnometer density, $\mathbf{g ~ c m}^{-3}$ \\
\hline $\mathrm{Ti}$ & 38 & 4.51 \\
$\mathrm{Zr}$ & 8 & 6.51 \\
$\mathrm{Fe}$ & 16 & 7.87 \\
\hline
\end{tabular}




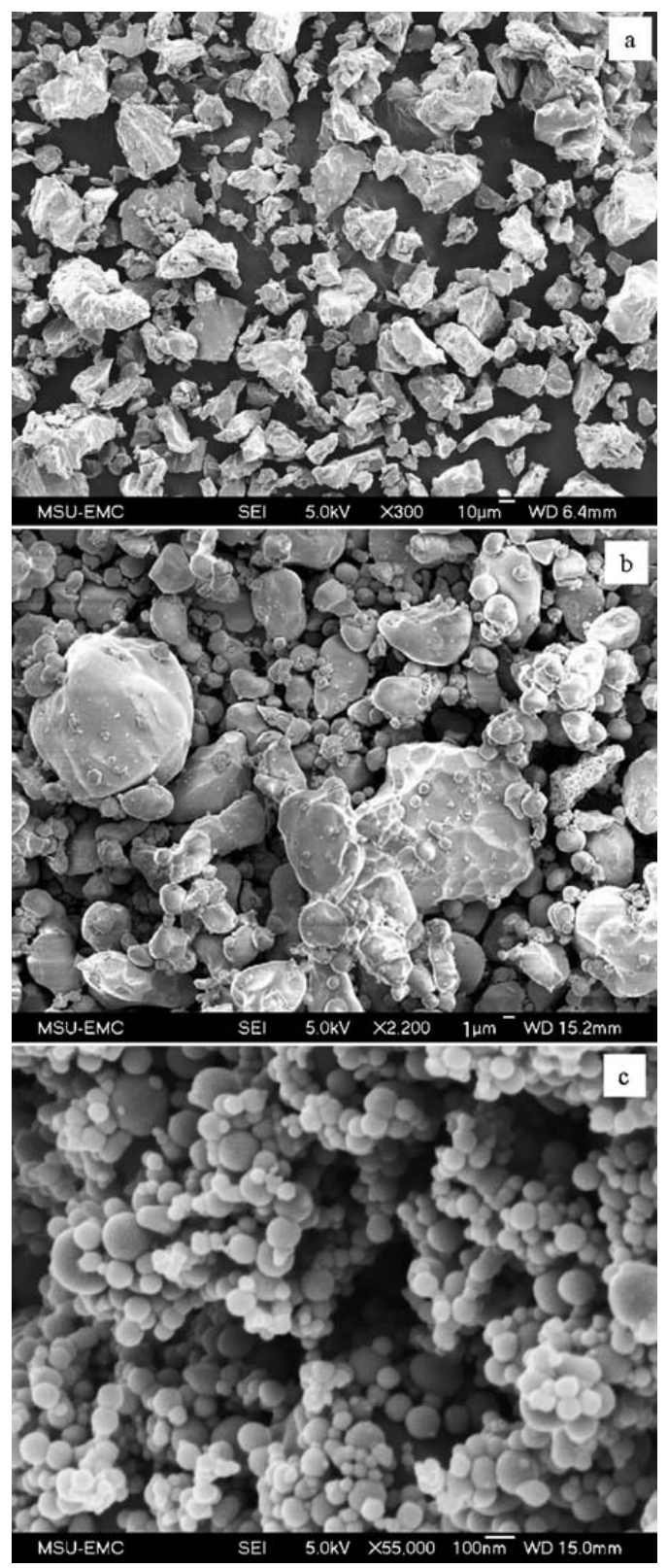

a $\mathrm{HDH}$ Ti powder; $b \mathrm{Zr}$ powder; $c$ Fe powder

1 Images (SEM) of three metal powders used in this study

has a tendency to stabilise the beta phase and form intermetallics while $\mathrm{Zr}$ has a tendency to promote chemical homogenisation. By optimising the sintering conditions and alloying it is possible to obtain nearly full density Ti structures via PIM.

This article provides a comparison of different PIM Ti alloys made using hydride-dehydride (HDH) Ti powder mixed with varying proportions of $\mathrm{Fe}$ and $\mathrm{Zr}$ to manipulate phase formation. The metal powder mixtures

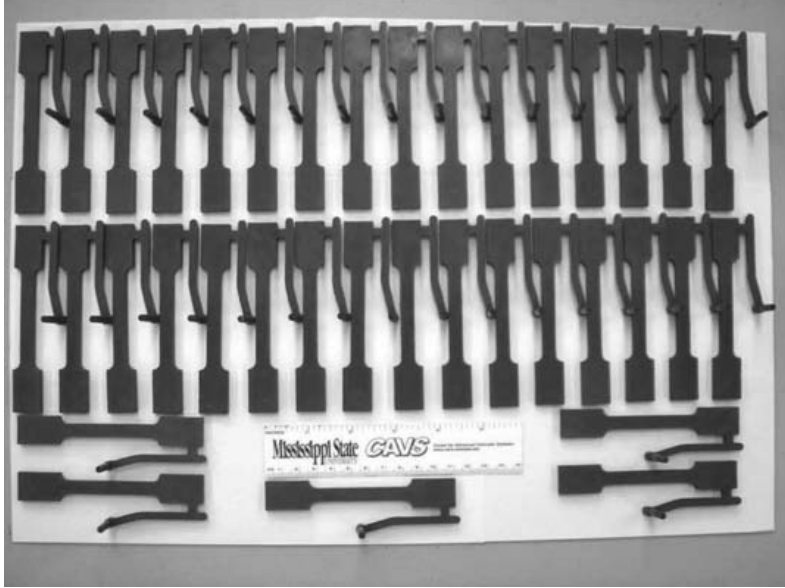

ONLINE COLOUR ONLY

2 Injection moulded $\mathrm{Ti}-5 \mathrm{Fe}-2 \cdot 5 \mathrm{Zr}$ parts

were mixed into a common wax based binder feedstock and injected and debound under the same conditions, which were determined using thermogravimetric analysis (TGA). Differential scanning calorimetry (DSC) was employed to guide selection of the optimal sintering range. Sintering was conducted at two different peak temperatures for two different hold times for each alloy to determine optimal sintering conditions. The properties and microstructure were evaluated using standard tensile, hardness and scanning electron microscopy (SEM) tools.

\section{Experimental}

\section{Characteristics of metal powder and binder}

The Ti powder used in this work was HDH Ti sponge powder provided by Phelly Materials (Bergenfield, NJ, USA). The $\mathrm{Zr}$ powder was obtained from Alfa Aesar (Ward Hill, MA, USA) and the Fe powder was obtained from Atlantic Equipment Engineers (Bergenfield, NJ, USA). All powders were -325 mesh and laser scattering particle size analysis was used to measure the size distribution; the mass based D10, D50 and D90 particle sizes give the 10, 50 and $90 \%$ points on the cumulative particle size distribution in Table 1 .

The morphology of each powder was examined by SEM. To protect the powders from oxidation, all of the materials were stored in an argon atmosphere except when mixing and moulding.

A standard binder system is employed, consisting of a paraffin wax (PW) and stearic acid (SA). High molecular weight polymer components used were polypropylene (PP) and polyethylene. A list of these binder components and their characteristics is given in Table 2 .

\section{Feedstock preparation}

Solids loading for this study was chosen to be 50 vol.- $\%$ to allow for easy flow of the feedstock during injection

Table 2 Properties of polymer binder components

\begin{tabular}{|c|c|c|c|c|c|c|}
\hline Material & Company & $\begin{array}{l}\text { Density, } \\
\mathrm{g} \mathrm{cm}^{-3}\end{array}$ & $\begin{array}{l}\text { Flash point, } \\
{ }^{\circ} \text { C }\end{array}$ & $\begin{array}{l}\text { Boiling point, } \\
{ }^{\circ} \mathrm{C}\end{array}$ & $\begin{array}{l}\text { Melting point, } \\
{ }^{\circ} \mathrm{C}\end{array}$ & $\begin{array}{l}\text { Binder, } \\
\text { wt- \% }\end{array}$ \\
\hline Fusabond MB-353D PP & DuPont & $0.88-0.98$ & 350 & $\ldots$ & $130-160$ & 9 \\
\hline IGI 1231A PW & $\begin{array}{l}\text { The International } \\
\text { Group, Inc. }\end{array}$ & 0.93 & $>190$ & $>300$ & $53 \cdot 3$ & 65 \\
\hline ProFlow 3000 PP & PolyVisions, Inc. & 0.9 & 315 & $\ldots$ & $>140$ & 25 \\
\hline SA & Fischer Chemicals & 0.84 & 196 & 361 & 69 & 1 \\
\hline
\end{tabular}

Powder Metallurgy 2010 VOL $000 \quad$ NO 000 


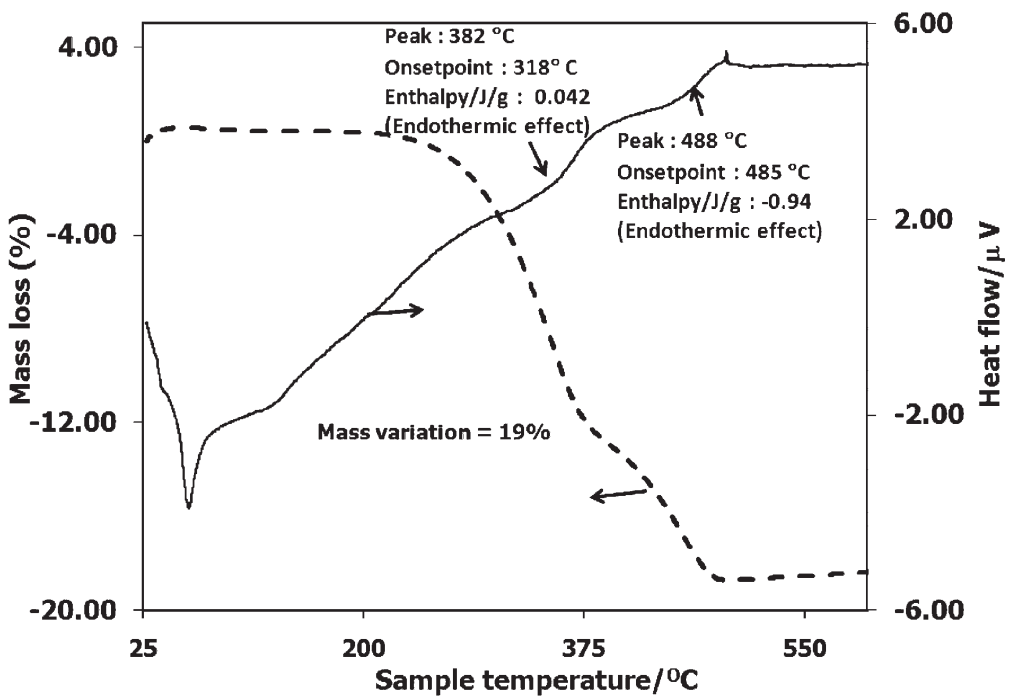

3 Differential scanning calorimetry experiments for binder removal evaluation

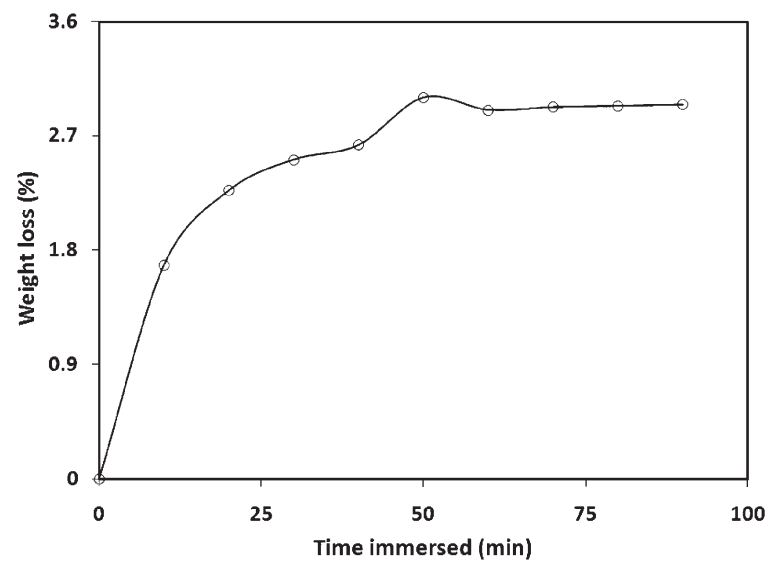

4 Binder removal rate in n-heptane

moulding. Mixing was done using an evacuated double planetary mixer with a thermally controlled mixing cup with a maximum volume of $\sim 1 \mathrm{~L}$. Binder components were melted first at a temperature of $150^{\circ} \mathrm{C}$ and mixed together at a rate of $60 \mathrm{~Hz}$ until the binder mixture was homogenous. The desired proportions of $\mathrm{Ti}, \mathrm{Zr}$ and $\mathrm{Fe}$ powders were manually mixed before being added to the melted binder mixture. The powder mixture was added in increments of $25 \%$ of the total metal powder volume to prevent unacceptable temperature loss and subsequent hardening of the binder material. The time allowed for thorough mixing after all powders were combined was 30 to $45 \mathrm{~min}$. After mixing, the feedstock was manually granulated before injection moulding.

\section{Thermal analysis}

To determine optimal thermal debinding conditions, TGA-DSC analysis was performed (SetSys Setaram

3 Instrumentation Technologies Inc., Caluire, France) on a sample of feedstock at a constant heating rate of $5 \mathrm{~K} \mathrm{~min}^{-1}$ in an argon atmosphere.

\section{Powder injection moulding}

Injection moulding was performed using a $20 \mathrm{t}$ Arburg Allrounder $170 \mathrm{U}$ injection moulding machine (Arburg

4 Ltd, Lossburg, Germany). The injection pressure was 750 bar at a fill rate of $10 \mathrm{~cm}^{3} \mathrm{~s}^{-1}$. The injection temperature was set to $160^{\circ} \mathrm{C}$ and the mould temperature

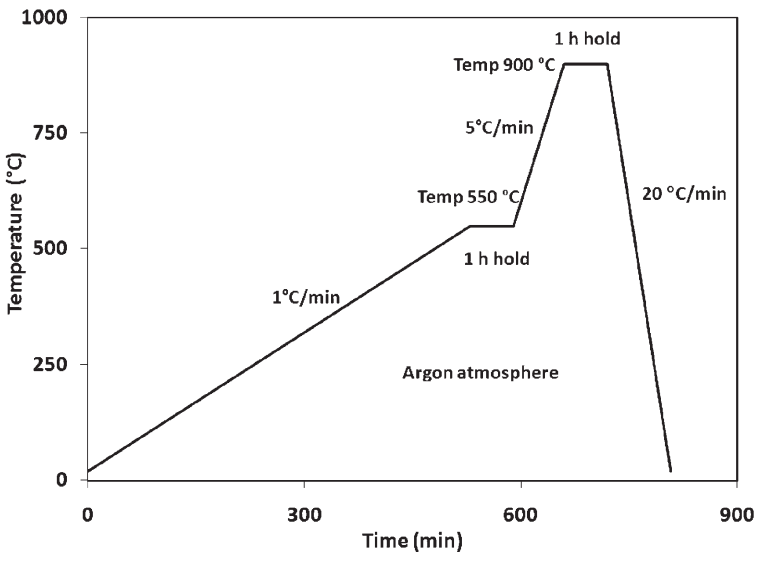

5 Optimum thermal debinding and presintering cycle

was held at $30^{\circ} \mathrm{C}$. The hold time was $6 \mathrm{~s}$ at a pressure of 375 bar. These conditions were uniform for the production of all test samples.

\section{Debinding}

\section{Solvent debinding}

Solvent debinding was done using $\mathrm{n}$-heptane at room temperature for periods of $10 \mathrm{~min}$, then dried and weighed to produce a weight loss curve.

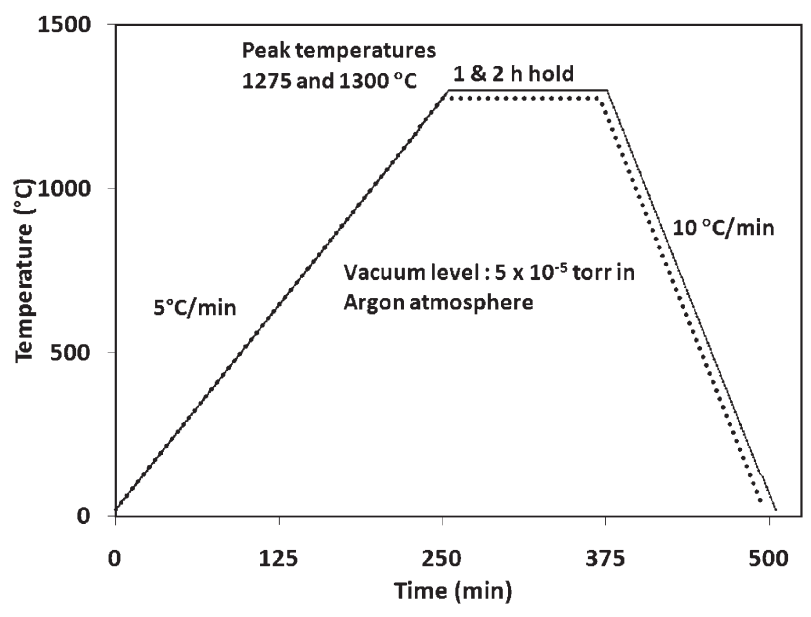

6 Sintering cycle for producing final part 
ONLINE COLOUR ONLY

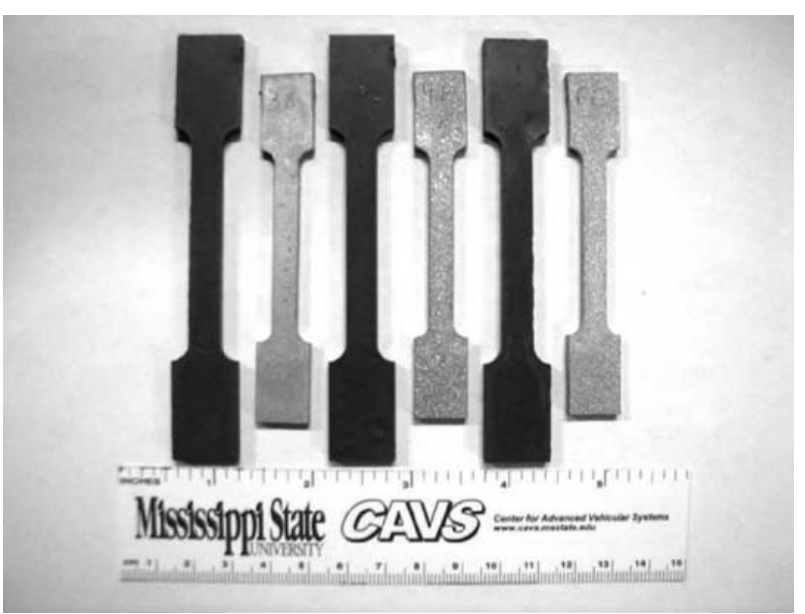

7 Green and sintered $90 \mathrm{Ti}-5 \mathrm{Fe}-5 \mathrm{Zr}$ parts arranged alternatively

\section{Thermal debinding and presintering}

The debinding temperature of $550^{\circ} \mathrm{C}$ was selected and reached at a heating rate of $1 \mathrm{~K} \mathrm{~min}^{-1}$ in an argon atmosphere. This temperature was held for $1 \mathrm{~h}$ to allow for polymer evaporation. Then the samples were further heated using a heating rate of $5 \mathrm{~K} \mathrm{~min}^{-1}$ up to $900^{\circ} \mathrm{C}$ for a hold time of $1 \mathrm{~h}$ to improve the green strength of the injected parts.

\section{Sintering}

After removing the binder and presintering, the components were sintered. Two sintering temperatures (1275 and $1300^{\circ} \mathrm{C}$ ) and two hold times ( 1 and $2 \mathrm{~h}$ ) were selected for this study. The Materials Research Furnace vacuum system used was an all metal hot zone $0.1 \mathrm{~m}^{3}$ volume equipped with four sided heating (Materials

5 Research Furnaces Inc., Suncook, NH, USA). At the peak temperature the furnace reached a vacuum of $6 \mathrm{kPa}$.

\section{Sample characterisation Density}

The Archimedes water immersion method was used for both green and sintered samples.

\section{Hardness}

The hardness tests were performed using a LECO-LR at

6 HRB scale (LECO Corporation, St. Joseph, MI, USA).

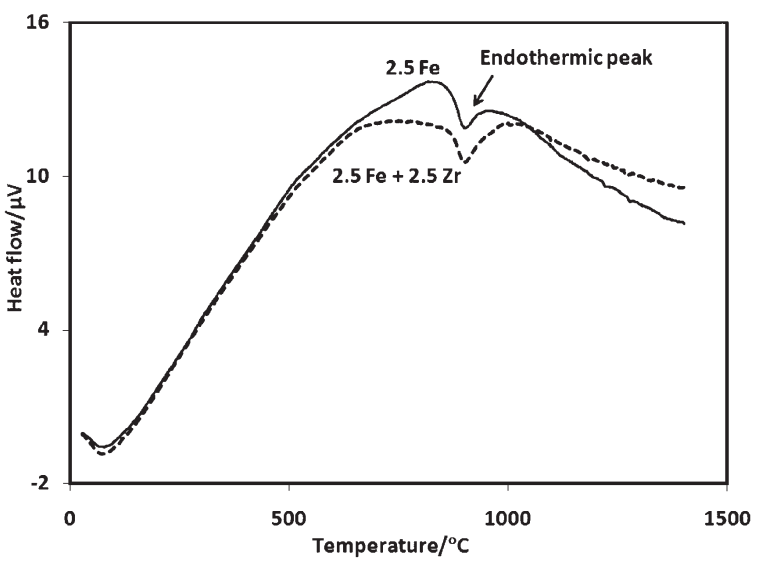

8 Differential scanning calorimetry experiment for low pressure sintering evaluation

At least ten measurements were made to ensure accuracy.

\section{Tensile test}

All tensile tests were performed using Instron 5569 (Instron Corporation, Norwood, MA, USA) mechanical 7 tested at a constant crosshead speed of $1 \mathrm{~mm} \mathrm{~min}^{-1}$ (25 mm gauge length).

\section{Microstructure}

Metallographic mounts of the sintered alloy were prepared using standard metallographic techniques. Microstructural characterisation was carried out using a JEOL SEM (JEOL Ltd, Tokyo, Japan). To observe the microstructure of the fractured sintered $\mathrm{Ti}$ alloys, Kroll's reagent ( $3 \mathrm{~mL} \mathrm{HF}, 6 \mathrm{~mL} \mathrm{HNO}_{3}$ in $100 \mathrm{~mL} \mathrm{H}_{2} \mathrm{O}$ ) was used to etch the samples for microscopy investigations. Energy dispersive X-ray spectroscopy (EDS) attached to SEM analysed the phases present within the microstructure of the sample.

\section{Results and discussion}

The SEM images of the powders used are shown in Fig. 1. As seen in these images, both the $\mathrm{Ti}$ and $\mathrm{Zr}$ powders exhibit irregular shapes. Though this will reduce the packing density of the two metals, the irregular shape should confer higher green strength on the powder assemblies. The characteristics of powders and binders used in this study are tabulated in Tables 1

Table 3 Mechanical properties of PIM Ti alloys

\begin{tabular}{|c|c|c|c|c|c|c|c|c|c|c|}
\hline \multirow[b]{2}{*}{ Alloy } & \multirow{2}{*}{$\begin{array}{l}\text { Sintering } \\
\text { temperature, } \\
{ }^{\circ} \mathrm{C}\end{array}$} & \multirow{2}{*}{$\begin{array}{l}\text { Hold } \\
\text { time, } \\
\mathrm{h}\end{array}$} & \multirow{2}{*}{$\begin{array}{l}\text { Theoretical } \\
\text { density, } \\
\mathrm{g} \mathrm{cm}^{-3}\end{array}$} & \multicolumn{2}{|c|}{ Green sample } & \multicolumn{5}{|c|}{ Sintered sample } \\
\hline & & & & $\begin{array}{l}\text { Density, } \\
\mathrm{g} \mathrm{cm}^{-3}\end{array}$ & $\begin{array}{l}\text { Relative } \\
\text { density, \% }\end{array}$ & $\begin{array}{l}\text { Density, } \\
\mathrm{g} \mathrm{cm}^{-3}\end{array}$ & $\begin{array}{l}\text { Relative } \\
\text { density, \% }\end{array}$ & $\begin{array}{l}\text { Hardness, } \\
\text { HRB }\end{array}$ & $\begin{array}{l}\text { Tensile } \\
\text { strain, \% }\end{array}$ & $\begin{array}{l}\text { UTS, } \\
\text { MPa }\end{array}$ \\
\hline \multirow[t]{4}{*}{$\mathrm{Ti}$} & 1275 & 1 & $4 \cdot 51$ & $2 \cdot 85$ & $63 \cdot 2$ & $3 \cdot 62$ & $80 \cdot 3$ & 58.9 & $1 \cdot 26$ & 190 \\
\hline & & 2 & & & & 3.92 & $86 \cdot 8$ & $67 \cdot 2$ & 1.87 & 539 \\
\hline & 1300 & 1 & & & & $3 \cdot 88$ & $86 \cdot 0$ & $64 \cdot 2$ & 0.99 & 540 \\
\hline & & 2 & & & & $3 \cdot 91$ & $86 \cdot 8$ & $69 \cdot 7$ & $1 \cdot 41$ & 517 \\
\hline \multirow{4}{*}{$\begin{array}{l}\mathrm{Ti}-5 \mathrm{Fe}- \\
2.5 \mathrm{Zr}\end{array}$} & 1275 & 1 & $4 \cdot 64$ & $2 \cdot 97$ & $64 \cdot 0$ & $4 \cdot 01$ & $86 \cdot 5$ & 72.9 & 0.84 & 459 \\
\hline & & 2 & & & & $4 \cdot 02$ & $86 \cdot 6$ & 76.9 & 0.89 & 508 \\
\hline & 1300 & 1 & & & & $4 \cdot 00$ & $86 \cdot 2$ & 71.9 & 0.32 & 237 \\
\hline & & 2 & & & & $4 \cdot 18$ & $90 \cdot 0$ & $81 \cdot 5$ & 2.08 & 512 \\
\hline \multirow{4}{*}{$\begin{array}{l}\mathrm{Ti}-5 \mathrm{Fe}- \\
5 \mathrm{Zr}\end{array}$} & 1275 & 1 & $4 \cdot 68$ & $3 \cdot 16$ & $67 \cdot 5$ & $4 \cdot 14$ & 88.6 & 74.5 & $2 \cdot 26$ & 410 \\
\hline & & 2 & & & & $4 \cdot 27$ & $91 \cdot 2$ & $75 \cdot 7$ & 0.94 & 530 \\
\hline & 1300 & 1 & & & & $4 \cdot 15$ & $88 \cdot 7$ & $74 \cdot 2$ & $1 \cdot 14$ & 548 \\
\hline & & 2 & & & & 3.91 & 83.5 & $72 \cdot 1$ & 0.00 & 198 \\
\hline
\end{tabular}




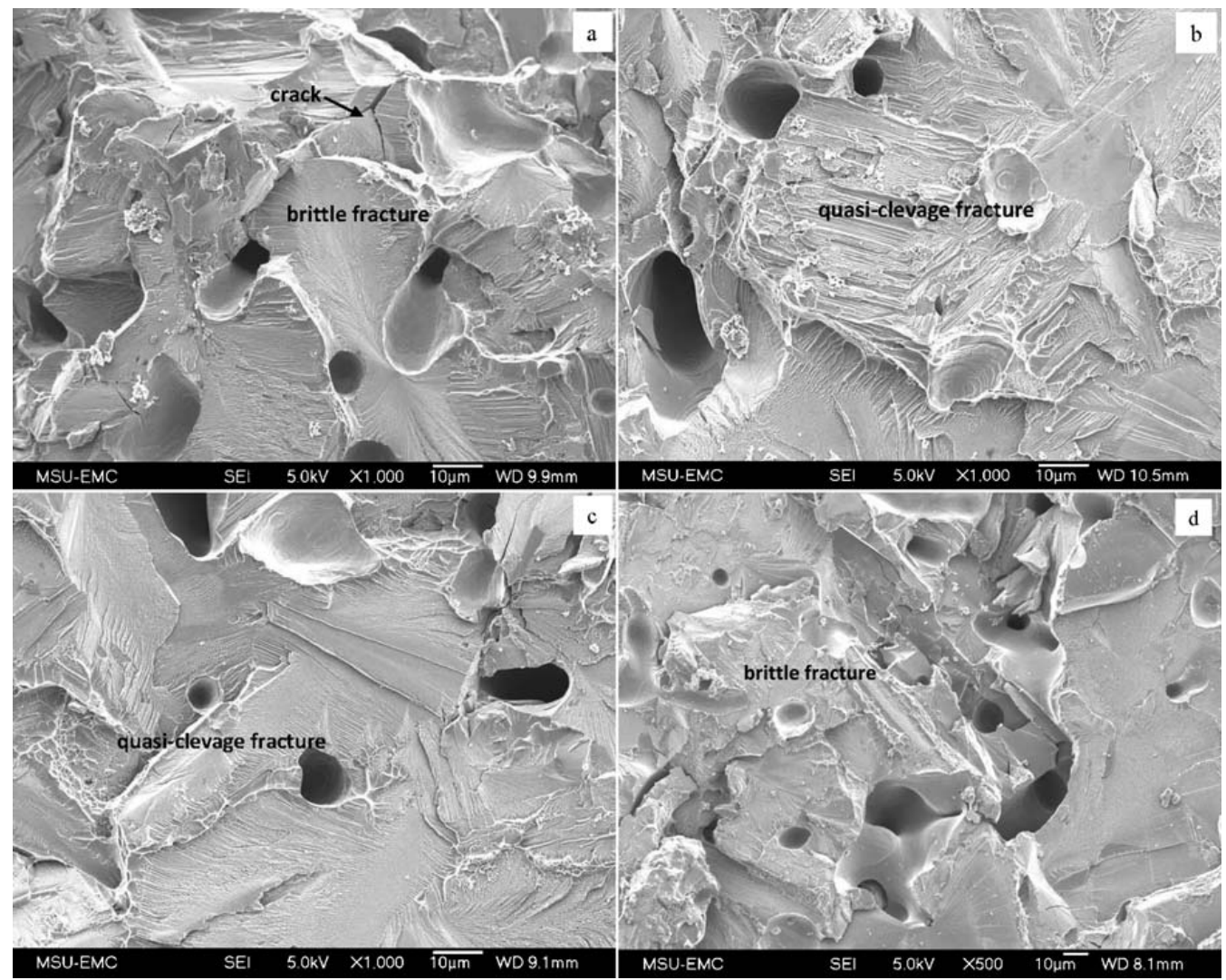

a $1275^{\circ} \mathrm{C}, 1 \mathrm{~h} ; b 1275^{\circ} \mathrm{C}, 2 \mathrm{~h} ; c 1300^{\circ} \mathrm{C}, 1 \mathrm{~h} ; d 1300^{\circ} \mathrm{C}, 2 \mathrm{~h}$

9 Fractographs of samples $90 \mathrm{Ti}-5 \mathrm{Fe}-5 \mathrm{Zr}$ sintered at different temperatures and hold times
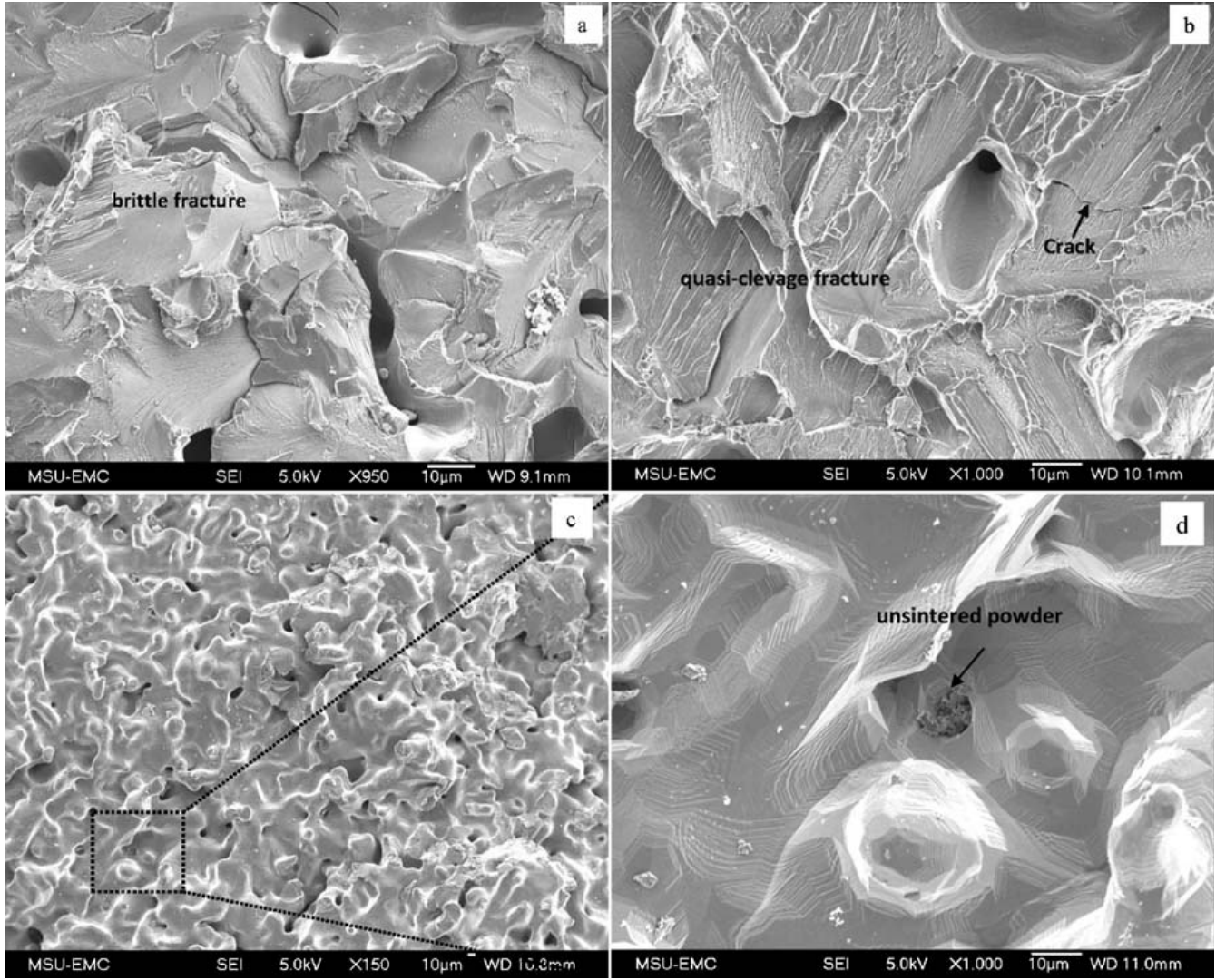

a $1275^{\circ} \mathrm{C}, 1 \mathrm{~h} ; b 1275^{\circ} \mathrm{C}, 2 \mathrm{~h} ; c 1300^{\circ} \mathrm{C}, 2 \mathrm{~h} ; d$ magnified region of $c$

10 Fractographs of samples $90 \mathrm{Ti}-5 \mathrm{Fe}-2 \cdot 5 \mathrm{Zr}$ sintered at different temperatures and hold times 


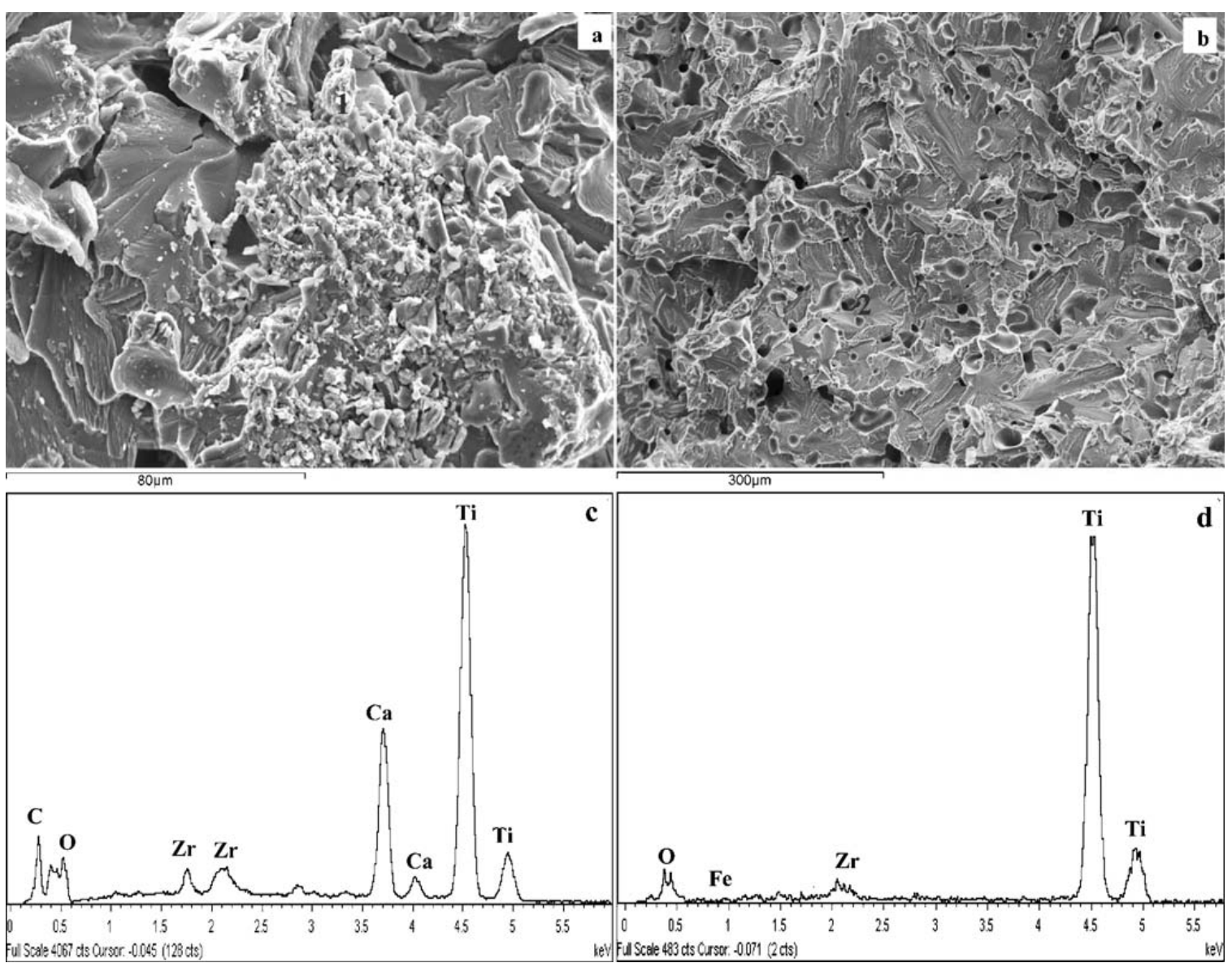

\section{ONLINE COLOUR ONLY}

$a, b$ SEM images; $c$ EDS analysis at location 1 in SEM image $a$; $d$ EDS analysis at location 2 in SEM image $b$

11 Images (SEM) and EDS analysis for Ti-5Fe-5Zr alloy: arrows indicate oxygen rich phases which are identified by EDS

and 2. Figure 2 shows photographs of the injection moulded parts.

Thermogravimetric analysis and differential thermal analysis traces obtained during debinding of the rods (solvent debinding and thermal debinding) are shown in Fig. 3. The low melting point binders (PW and SA) are first to be removed from the parts completely in the temperature range of $230-370^{\circ} \mathrm{C}$ and show a characteristic endothermic peak with an enthalpy of $0.042 \mathrm{~J} \mathrm{~g}^{-1}$. High molecular weight binder material was removed thereafter up to $470^{\circ} \mathrm{C}$ and showed an endothermic peak with an enthalpy of $0.94 \mathrm{~J} \mathrm{~g}^{-1}$.

Figure 4 shows the binder removal in n-heptane (solvent debinding). The binder loss gradually increases with immersion time and temperature. A $90 \mathrm{~min}$ immersion at $60^{\circ} \mathrm{C}$ removed almost $95 \%$ of the soluble binders. At this stage a dynamic equilibrium is established between the diffusion-dissolution kinetics of solvent and soluble binder materials.

Figure 5 shows the optimum thermal debinding and presintering cycle. Initially a very low heating rate of $1 \mathrm{~K} \mathrm{~min}^{-1}$ up to $550^{\circ} \mathrm{C}$ was preferred to remove the remaining binders. These conditions are ideal for generating parts free from bubbling, defects and cracks. Thereafter the heating rate was raised to $5 \mathrm{~K} \mathrm{~min}^{-1}$ till $550^{\circ} \mathrm{C}$ with a hold time of $1 \mathrm{~h}$ to presinter the rods. This condition was intended to improve the strength of the rods. The sintering cycle for producing the final parts and photographs of the green and sintered parts are shown in Figs. 6 and 7 respectively.
Table 3 shows the mechanical properties of PIM Ti and $\mathrm{Ti}-\mathrm{Fe}-\mathrm{Zr}$ alloy and Fig. 7 shows the photograph of green and sintered $90 \mathrm{Ti}-5 \mathrm{Fe}-5 \mathrm{Zr}$ alloy. As expected the green density of Ti increased with increased addition of $\mathrm{Zr}$ and $\mathrm{Fe}$. This is due to the density differences for pure $\mathrm{Ti}$ and $\mathrm{Ti}-\mathrm{Fe}-\mathrm{Zr}$ powder mixtures. The green densities of $\mathrm{Ti}, 92 \cdot 5 \mathrm{Ti}-5 \mathrm{Fe}-2 \cdot 5 \mathrm{Zr}$ and $90 \mathrm{Ti}-5 \mathrm{Fe}-5 \mathrm{Zr}$ alloys were $2 \cdot 85,2 \cdot 97$ and $3 \cdot 16 \mathrm{~g} \mathrm{~cm}^{-3}$ respectively. Also as expected, Ti samples without $\mathrm{Fe}$ and $\mathrm{Zr}$ additions resulted in a maximum theoretical density of $86 \%$ whereas the addition of $\mathrm{Fe}$ and $\mathrm{Zr}$ in 2.5 and $5.0 \mathrm{wt}-\%$ increased the theoretical density to $91 \%$. The increase in theoretical density is accounted for by the formation of liquid phase in the temperature range of $980-1065^{\circ} \mathrm{C}$ which enhances the densification of the alloy owing to the diffusion in the liquid phase along the grain boundaries. Figure 8 shows endothermic peaks found in DSC traces of Ti alloy powder when mixed with $\mathrm{Zr}$ and $\mathrm{Fe}$ powders which provides evidence of liquid phase formation. The presence of $\mathrm{Fe}$ and $\mathrm{Zr}$ assists sintering by the formation of a liquid phase. The liquid phase remains as an almost continuous network between solid grains, favouring the classical phenomenon of the liquid phase sintering. ${ }^{5}$

The maximum tensile strength obtained in PIM Ti was in the range of $190-548 \mathrm{MPa}$. Because of the variability in residual porosity, a lot of scatter in the results was observed. In some cases interconnected porosity was observed which can cause significant reduction in tensile strength. Figures 9 and 10 illustrate the existence of pores, brittle fracture regions and other 
defect regions, caused by poor densification and sintering response. In addition, SEM-EDS results shown in Fig. 11 revealed the presence of oxide and calcium as impurities in the sintered $\mathrm{Ti}-5 \mathrm{Fe}-5 \mathrm{Zr}$. The impurity levels in these cases were $30 \mathrm{wt}-\% \mathrm{O}$ and $17 \mathrm{wt}-\% \mathrm{Ca}$.

Ductility change was more drastic with $\mathrm{Fe}$ and $\mathrm{Zr}$ addition. The highest hardness was obtained with the highest sintered density samples. A maximum hardness near $81 \mathrm{HRB}$ was reached with $5 \mathrm{Fe}$ and $2 \cdot 5 \mathrm{Zr}$ additions. The scanning electron micrographs of the sintered samples evidenced poor final stage densification. This might be corrected by a higher sintering temperature, but often grain growth and phase transformations offset the gains from densification, leading to a decrement in strength even though density increases.

\section{Conclusions}

The addition of $\mathrm{Fe}$ and $\mathrm{Zr}$ to a low cost $\mathrm{Ti}$ powder provided some benefit in terms of sintering densification and hardness, but did not produce significant improvements in strength or ductility. The maximum sintered density achieved in this study was $91 \%$ for a $90 \mathrm{Ti}-5 \mathrm{Fe}-$ $5 \mathrm{Zr}$ alloy. The formation of liquid phase gives some densification and hardness gain, but the high residual porosity and brittle fracture associated with the alloying the sintered lower tensile properties.

\section{References}

1. Y. Xu and H. Nomura: J. Jpn Soc. Powder Powder Metall., 2001, 48, (11), 1089-1096.

2. R. Gerling and F. P. Schimansky: Mater. Sci. Eng. A, 2002, A329A331, 45-49.

3. S. Terauchi, T. Teraoka, T. Shinkuma and T. Sugimoto: J. Jpn Soc. Powder Powder Metall., 2000, 47, (12), 1283-1287.

4. F. H. Froes and R. M. German: Met. Powder Rep., 2000, 55, (6), $12-21$.

5. R. M. German: Powder Inject. Moulding Int., 2009, 3, (4), 21-37.

6. J. R. Alcock, M. W. Darlington and D. J. Stephenson: Powder Metall., 1996, 39, (4), 252-254.

7. T. Uematsu, Y. Itoh, K. Sato and H. Miura: J. Jpn Soc. Powder Powder Metall., 2006, 53, (9), 755-759.

8. K. S. Weil, E. Nyberg and K. Simmons: J. Mater. Process. Technol., 2006, 176, (1-3), 205-209.

9. Y. Itoh, Y. Harikou, K. Satoh and H. Miura: J. Jpn Soc. Powder Powder Metall., 2005, 52, (1), 43-48.

10. D. Kuroda, M. Niinimi, M. Morinaga, Y. Kato and T. Yshiro: Mater. Sci. Eng. A, 1998, A243, (1-2), 244-249.

11. K. Kato, A. Matsumoto and T. Leki: J. Jpn Soc. Powder Powder Metall., 1997, 44, (11), 1029-1034.

12. T. Leki, K. Katoh, A. Matsumoto, T. Masui and K. Andoh: J. Jpn Soc. Powder Powder Metall., 1997, 44, (5), 448-452.

13. S. J. Park, D. F. Heaney and R. M. German: Metall. Mater. Trans. A, 2009, 40A, (1), 215-222.

14. W. Wei, Y. Liu, K. Zhou and B. Huang: Powder Metall., 2003, 46, (3), 246-250.

15. F. G. Li, X. L. Yu, L. K. Jiao and Q. Wan: Mater. Sci. Eng. A, 2006, A430, (1-2), 216-220. 


\section{Authors Queries}

Journal: Powder Metallurgy

Paper: 1641

Title: Effect of additives on sintering response of titanium by powder injection moulding

\section{Dear Author}

During the preparation of your manuscript for publication, the questions listed below have arisen. Please attend to these matters and return this form with your proof. Many thanks for your assistance

\begin{tabular}{|c|c|c|}
\hline $\begin{array}{l}\text { Query } \\
\text { Reference }\end{array}$ & Query & Remarks \\
\hline 1 & $\begin{array}{l}\text { Author: Please confirm the loca- } \\
\text { tion. }\end{array}$ & \\
\hline 2 & $\begin{array}{l}\text { Author: Please confirm the loca- } \\
\text { tion. }\end{array}$ & \\
\hline 3 & $\begin{array}{l}\text { Author: Please confirm the loca- } \\
\text { tion. }\end{array}$ & \\
\hline 4 & $\begin{array}{l}\text { Author: Please confirm the sup- } \\
\text { plier and its location. }\end{array}$ & \\
\hline 5 & $\begin{array}{l}\text { Author: Please confirm the sup- } \\
\text { plier and its location. }\end{array}$ & \\
\hline 6 & $\begin{array}{l}\text { Author: Please confirm the sup- } \\
\text { plier and its location. }\end{array}$ & \\
\hline 7 & $\begin{array}{l}\text { Author: Please confirm the sup- } \\
\text { plier and its location. }\end{array}$ & \\
\hline 8 & $\begin{array}{l}\text { Author: Please confirm the sup- } \\
\text { plier and its location. }\end{array}$ & \\
\hline 9 & $\begin{array}{l}\text { Author: Please check this sen- } \\
\text { tence. }\end{array}$ & \\
\hline
\end{tabular}

